Journal of Business and Management Studies (JBMS)

ISSN: $2709-0876$

DOI: $10.32996 / \mathrm{jbms}$

Journal Homepage: www.al-kindipublisher.com/index.php/jbms

\title{
The Relationship Between Trust and Intention to Recommend: The Role of Content Quality, Website Design and Enjoyment
}

\author{
Amanda Yuliana ${ }^{1} \square$ and Lilik Wahyudi ${ }^{2}$ \\ ${ }^{12}$ Sebelas Maret University, Surakarta, Indonesia \\ $\square$ Corresponding Author: Amanda Yuliana, E-mail: amandaayulianaa@gmail.com
}

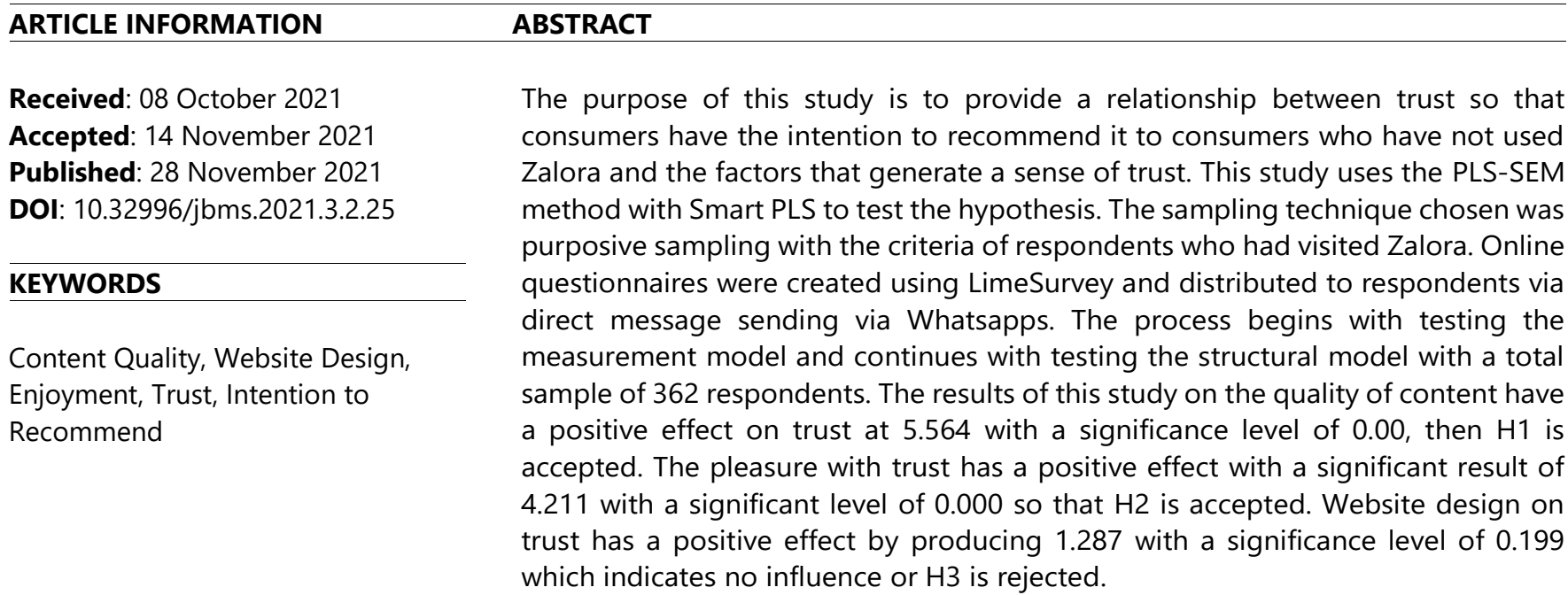

\section{Introduction}

The development of internet-based technology has experienced very rapid growth and the benefits of internet-based technology have become a boon for the world of business and trade. With this, it will trigger movements in which the world of business and trade switches to using the internet. Social trading sites are not only a tool to support business transactions as well as become a channel for companies to connect and communicate with consumers (Al-Maghrabi et al., 2011). Trading via websites and social media is gaining immense popularity and is becoming a popular place offering a wide range of products, information, and services that contribute to marketers (Wang \& Lin, 2017). The expectations of consumers who use online shopping sites continue to increase every year and in order to retain consumers who use these online sites, it is necessary to rework strategies in order to meet consumer expectations and trust (Penny Gillespie, Gene Alvarez, Yanna Dharmasthira, David Kohler, Jason Daigler, 2015). Trust in doing business online is the most superior advantage in using e-commerce (Hart \& Saunders, 1997; Strauss, 2012) (Heil, 2000) where online shopping sites directly change in terms of technology and include relationships in business.

Zalora's growth in consumers also has results which according to the Top Brand Award have been stable in the last 5 years, nothing has dropped drastically according to the Top Brand Award. Zalora, which is dominated by online fashion, beauty, lifestyle which is number 1 in Asia in the annual reporting period in 2020, has increased 14 times (ZALORA, 2020). Trends in healthy lifestyles and sporting activities that are increasing from year to year make consumers have more needs in this fashion style trend, therefore with Zalora, it increases higher with the intention to recommend.

Copyright: (c) 2021 the Author(s). This article is an open access article distributed under the terms and conditions of the Creative Commons Attribution (CC-BY) 4.0 license (https://creativecommons.org/licenses/by/4.0/). Published by Al-Kindi Centre for Research and Development, London, United Kingdom. 


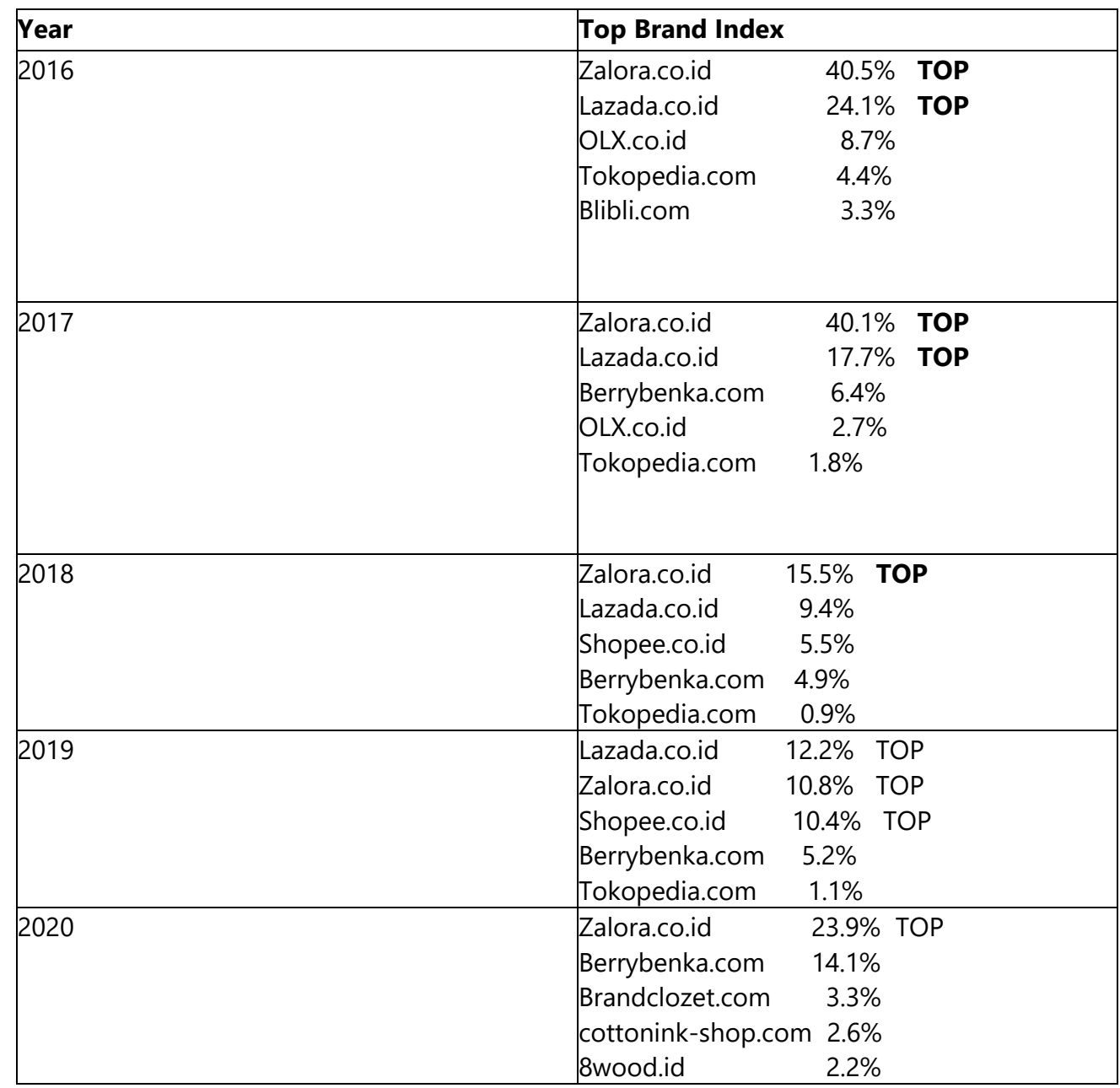

Source: (Top Brand Index, nd)

The higher level of satisfaction will have an impact on customer loyalty such as consumer repurchasing, word of mouth promotion (word of mouth) (Anderson \& Sullivan, 1993; Nowlin et al., 2018; Shankar et al., 2003). In the context of online media that satisfaction and trust have a significant influence on the tendency of consumers to provide reviews that are in accordance with consumers (Harris \& Goode, 2004; Kim et al., 2009; Ranaweera \& Prabhu, 2003). In this study, we will further explore the intention to recommend through the quality of content, website design, and the pleasure of trust in using and transacting on online shopping sites.

\section{Theory Basis}

\subsection{Trust}

Trust is one of the most important elements in an online platform (Arjoon \& Rambocas, 2011). Loyal online consumers will provide benefits for online site providers, consumer trust is the basis for providing satisfaction and a way to maintain long-term online site relationships (Walczuch \& Lundgren, 2004). According to (Cheung et al., 2015) trust is the basis for e-commerce to be strategic for interaction between consumers and marketers. Likewise, developing consumer trust is very meaningful and important for the development and growth of e-commerce.

The quality of content that expresses consumer perceptions of service content is more effective by e-commerce sites in providing activity facilities for online shopping (Tang et al., 2013) (Heijden et al., 2003). Quality content through functions on online websites can provide facilities regarding product search, save online purchases and promote consumer relations as well as consumers and retailers. Predicting tagged, accurate and useful information about a product or service on an online site can increase trust in using e-commerce. In addition, accessing online sites with easy understanding can provide convenience for consumers (Fan et al., 2013; Hausman \& Siekpe, 2009)

In a study conducted by (Liao et al., 2006) it was found that quality content has a positive effect on trust. It was explained in previous research that trust will quickly disappear if consumers feel the quality of the information provided on the content is inaccurate, if the content makes inaccurate information it will affect doubts and consumers and sellers. Addressing the results of 
research (De Ruyter et al., 1998; Jones et al., 2002) that service quality is positively related to purchase intentions, recommendations. Conversely, by providing quality content, the level of trust will also increase, so the following hypothesis can be taken:

\section{$H_{1}$ Content quality has a positive effect on trust}

The appearance of the website is the overall appearance of the website that has been felt according to the consumer's point of view. Making the concept of a comprehensive view determines the quality of the website (Dodds et al., 1991; Yoo et al., 2001). Website design is very important because it has a role in retaining consumers (Liang \& Lai, 2002)With a high-quality website design, will influence purchasing decisions and influence whether consumers buy online or not (Gehrke \& Turban, 2003)

In a previous study by (Liao et al., 2006) that website design has a positive effect on trust. Consumers think that if the website design is of high quality, consumers will tend to have a high sense of trust regarding competence, integrity and develop a mutual will to depend on each other (McKnight et al., 2002). Therefore, from this research it will be concluded with the following hypothesis:

\section{$\mathrm{H}_{2}$ Website design has a positive effect on trust}

Pleasure is categorized with technology whereby using technology you can feel pleasure appearing by itself (Venkatesh \& Davis, 2000). Consumer perceptions of pleasure are consumer activities in interacting on online sites that are considered pleasure. a sense of pleasure which refers to the extent to which internet-based technology is useful when used (Lowry et al., 2013) that views and cultural traits that prioritize the quality of life, care for others (Rouibah, 2008). Previous research from (Hwang \& Kim, 2007) found that consumers saw the use of online payments as more enjoyable and that consumers were more likely to have more time to get things done and tend to trust online payments. So from this research, the following hypothesis is drawn:

\section{$\mathrm{H}_{3}$ Pleasure has a positive effect on trust}

\subsection{Intention to Recommend}

Intentions to recommend can help consumers determine or find the type of product or brand that can be said to be attractive by personalizing from historical data, opening notes (Bo \& Benbasat, 2007). Recommending e-commerce can increase sales and online commerce (Wei et al., 2007) a potential boost for buyers and can build customer loyalty (Zhu et al., 2014)

Research findings by (Garbarino \& Johnson, 1999; Singh \& Sirdeshmukh, 2000) give the results that if the level of trust is higher, it will increase a greater tendency to recommend to others will cause a sense of fun. Supported by research from Rakhi Thakur 2018 that trust has a positive influence on online review intentions. Trust provides benefits to consumers such as the emergence of low anxiety, uncertainty, and range for transactions. The results of the study (Al-Ansi et al., 2019) show that trust is significant and has a positive effect on the intention to recommend. Therefore, this study proposes the following:

\section{$\mathrm{H}_{4}$ Trust has a positive effect on the intention to recommend}

\section{Research Method}

\subsection{Sample and Procedure}

This research is a hypothesis testing using a cross-section survey to collect primary data in the field. The sampling technique was selected using purposive sampling with the criteria of respondents who have visited Zalora. An online questionnaire was created using LimeSurvey and distributed to respondents by sending direct messages via Whatsapps. In total 362 respondents filled out the questionnaire. The data screening process is carried out to obtain respondents who have complete data and meet the criteria. The process produces the remaining 213 data.

\subsection{Measurement}

To get the data or information needed in this research, an instrument is needed. This instrument is important to measure various influences, relationships, and direction of variables in this research model. The research instrument in this thesis is a series of questions that are needed to form various constructs of variables - either the dependent variable or the independent variable. The instrument used in this study was a questionnaire that was taken and modified from various questionnaires used by several previous researchers. Researchers used self-report questionnaires to assess content quality, website design, enjoyment, trustworthiness, and intention to recommend.

\subsection{Hypothesis Testing}

This study uses the PLS-SEM method with Smart PLS to test the hypothesis. The process begins with testing the measurement model and continues with testing the structural model. 


\section{Results and Discussion}

\subsection{Respondent's Description}

The online survey was conducted using LimeSurvey. From a total of 362 respondents who participated 213 respondents filled in completely and met the criteria. The profiles of respondents who filled in completely can be seen in the following table:

Table 1 Characteristics of Respondents

\begin{tabular}{|l|l|l|}
\hline Description & Information & Percentage \\
\hline \multirow{4}{*}{ Agender } & Man & $38.5 \%$ \\
\cline { 2 - 3 } & Woman & $61.5 \%$ \\
\hline \multirow{5}{*}{ Level of education } & $15-25$ years & $44.1 \%$ \\
\cline { 2 - 3 } & $26-40$ years old & $9.9 \%$ \\
\cline { 2 - 3 } & Over 40 years & $46.0 \%$ \\
\hline Income & High School/Equivalent & $16.9 \%$ \\
\cline { 2 - 3 } & Diploma $(\mathrm{D} 3)$ & $12.7 \%$ \\
\cline { 2 - 3 } & Bachelor degree) & $60.6 \%$ \\
\cline { 2 - 3 } & Master $(\mathrm{S} 2)$ & $9.9 \%$ \\
\hline & $<2,500,000$ & $34.3 \%$ \\
\cline { 2 - 3 } & $2,500,000-5,000,000$ & $39.4 \%$ \\
\cline { 2 - 3 } & $5,000,000-7,500,000$ & $12.7 \%$ \\
\cline { 2 - 3 } & $7,500,000-10,000,000$ & $8.0 \%$ \\
\cline { 2 - 3 } & $>10,000,000$ & $5.6 \%$ \\
\hline
\end{tabular}

Source: Data processed

Based on gender, most of the respondents were female at $61.5 \%$, and the remaining $38.5 \%$ were male respondents. Based on age, the majority of respondents were respondents aged over 40 years at $46 \%$ followed by respondents aged 15.25 years at $44.1 \%$, and the remaining respondents aged $26-40$ years at $9.9 \%$. Based on the level of education, the largest respondents are respondents with an undergraduate education level (S1) of $60.6 \%$ followed by respondents with a high school education level/equivalent of $16.9 \%$ and Diploma (D3) education at $12.7 \%$, the remaining Masters (S2) at $9.9 \%$. Based on the income level, most of the respondents have income levels between 2.5 million to 5 million by $39.4 \%$ followed by income levels below 2.5 million by $34.3 \%$ and income levels between 5 million to 7.5 million sbsar 12, 7\%. For the income level between 7.5 million to 10 million, $8 \%$ and the remaining income level above 10 million is $5.6 \%$.

\subsection{Measurement Model Testing}

Data analysis begins with testing the measurement model and continues with testing the structural model. The results of the structural model testing can be seen in Table 2 below: 


\begin{tabular}{|c|c|c|c|c|c|}
\hline \multirow[t]{2}{*}{ Construct } & Items & Factor & Cronbach & Composite & AVE \\
\hline & & \multicolumn{2}{|c|}{ Loading Alpha } & Reliability & \\
\hline \multirow[t]{5}{*}{ Content Quality } & CQ1 & 0.862 & 0.949 & 0.957 & 0.788 \\
\hline & CQ2 & 0.927 & & & \\
\hline & CQ3 & 0.894 & & & \\
\hline & CQ4 & 0.878 & & & \\
\hline & CQ5 & 0.875 & & & \\
\hline \multirow[t]{3}{*}{ Website Design } & WEBD1 & 0.600 & 0.856 & 0.903 & 0.706 \\
\hline & WEBD2 & 0.913 & & & \\
\hline & WEBD3 & 0.917 & & & \\
\hline WEBD4 & & 0.888 & & & \\
\hline \multirow{6}{*}{ Enjoyment } & ENJ1 & 0.870 & 0.975 & 0.980 & 0.889 \\
\hline & ENJ2 & 0.936 & & & \\
\hline & ENJ3 & 0.947 & & & \\
\hline & ENJ4 & 0.956 & & & \\
\hline & ENJ5 & 0.969 & & & \\
\hline & ENJ6 & 0.975 & & & \\
\hline \multirow[t]{3}{*}{ Trust } & TRST1 & 0.936 & 0.939 & 0.961 & 0.892 \\
\hline & TRST2 & 0.965 & & & \\
\hline & TRST3 & 0.932 & & & \\
\hline \multirow[t]{4}{*}{ Intention to Recommend } & REVR1 & 0.946 & 0.943 & 0.959 & 0.854 \\
\hline & REVR2 & 0.925 & & & \\
\hline & REVR3 & 0.895 & & & \\
\hline & REVR4 & 0.931 & & & \\
\hline
\end{tabular}

Source: Data processed

The test results show the loading factor value for all indicators has a value above 0.7 except for WEBD1 (0.600). According to Hair et al (2017), a score between 0.4-0.7 is considered to be deleted when it has an impact on the composite reliability score. The simulation results show that there is no impact, so the item is maintained. Cronbach alpha, composite reliability, and AVE tests show values above the standard, all of which indicate the criteria for a good measurement model. Discriminant validity testing using Fornell-Larcker criteria can be seen in Table 3 below:

Table 3. Fornell-Larcker Criterion

\begin{tabular}{|l|l|l|l|l|c|}
\hline & $\begin{array}{l}\text { Quality } \\
\text { Content }\end{array}$ & $\begin{array}{l}\text { fun } \\
n\end{array}$ & $\begin{array}{l}\text { Intention } \\
\text { Recommen } \\
\mathrm{d} \\
\text { make it easy }\end{array}$ & $\begin{array}{l}\text { Trust } \\
\text { an }\end{array}$ & $\begin{array}{l}\text { Design } \\
\text { Website }\end{array}$ \\
\hline Content Quality & $\mathbf{0 . 8 8 8}$ & & & & \\
\hline Enjoyment & 0.723 & $\mathbf{0 . 9 4 3}$ & & & \\
\hline Intention to Recommend & 0.761 & 0.746 & $\mathbf{0 . 9 2 4}$ & & \\
\hline Trust & 0.764 & 0.710 & 0.700 & $\mathbf{0 . 9 4 4}$ & \\
\hline Website Design & 0.800 & 0.723 & 0.735 & 0.690 & $\mathbf{0 . 8 4 0}$ \\
\hline
\end{tabular}

Source: Data processed

Table 3 shows that each variable studied has the highest value, so it can be said that it passes the Fornell and Larcker criteria

\subsection{Structural Model Testing}

The process of testing the structural model is carried out after the measurement model meets the required criteria. Improvements are made if there are problems in the measurement model. The existing test results show that all of the measurement model testing criteria are met so that the process can proceed to the structural model. The structural model in this study can be seen in the following figure: 


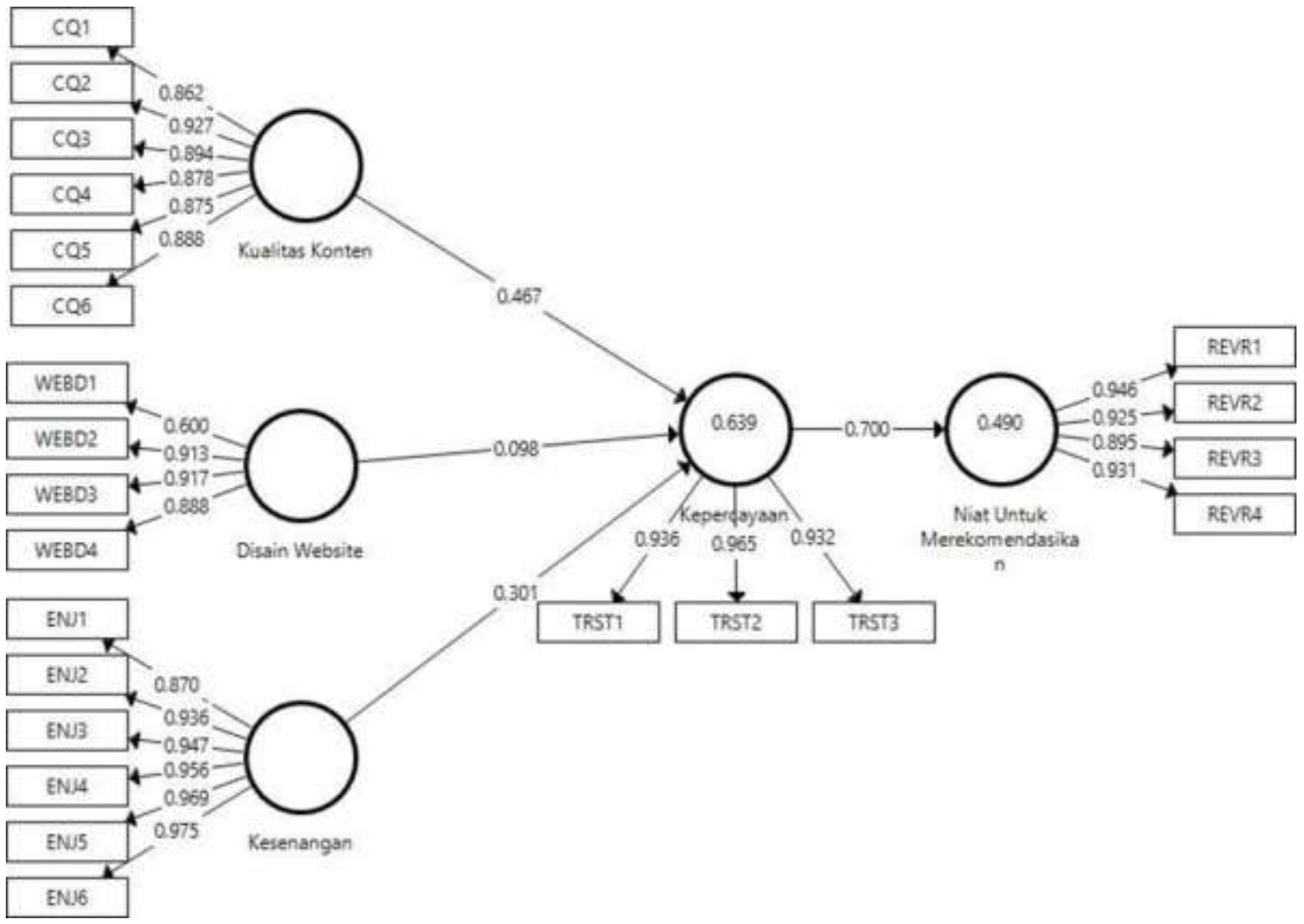

Figure 1. Structural Model and Test Results

Hypothesis testing has a standard $t$ value of 1.96 for the respondent data above 120. If the value of the $t$ statistic is greater than 1.96 then $\mathrm{H}_{0}$ is rejected and $\mathrm{H}_{a}$ accepted. test result The complete hypothesis can be seen in Table 4 below:

Table 4 Hypothesis Testing Results

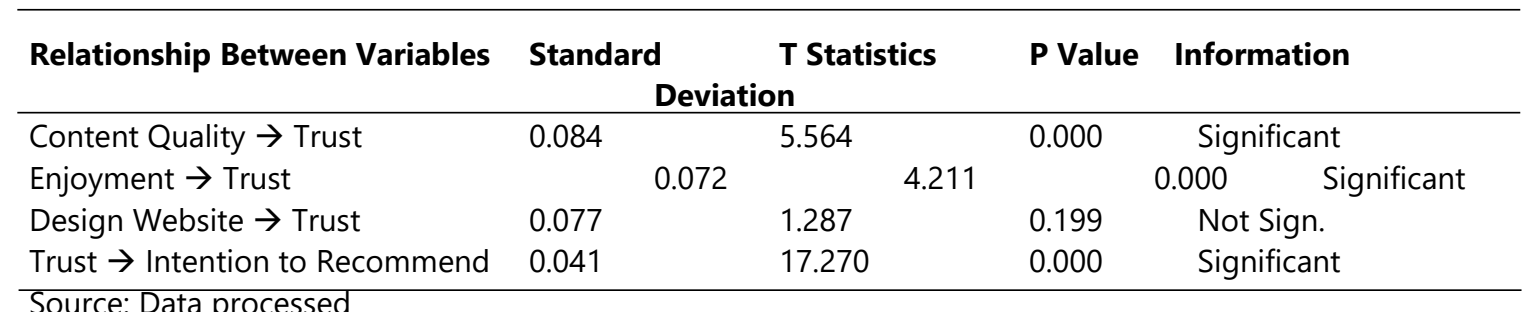

Source: Data processed

The results of testing the hypothesis of a positive influence between the quality of content on trust, the results of the $\mathrm{t}$-stat test value of 5.564 and p-value of 0.000 . From the test results, it can be concluded that $\mathrm{H}_{1}$ accepted, the quality of the content has a positive effect on trust. Testing the positive effect of pleasure on trust shows significant results ( $t$-stat 4.211, p-value 0.000 ) so that $\mathrm{H}_{2}$ is accepted. While testing the positive influence of website design on trust shows a t-stat value of 1.287 with a p-value of 0.199 which indicates no effect or $\mathrm{H}_{3}$ rejected. Existing test results show that Indonesian consumers are getting smarter, consumers are more concerned with the quality of content and fun than website design. The results of this study are in line with research (Lee, 2018), (Konuk, 2018), (Panjakajornsak, Perceived quality, perceived risk and customer trust affecting customer loyalty of environmentally friendly electronics products. 2017) which shows a strong influence of content quality on trust consumer. The results of the study are also in line with the research of Bukhari et al (2013) and Kumar et al (2018) which show a strong influence between pleasure on trust.

The results of testing the effect of trust on the intention to recommend obtained the results of a t-stat value of 17.270 and a pvalue of 0.000 . The test results show that there is a strong influence between trust and intention to recommend which means $\mathrm{H} 4$ accepted. The very strong influence shows that trust is a strong predictor of intention to recommend. 


\section{Conclusions and Suggestions}

This research is expected to make it easier for readers to understand what is related to the results of this study. Consumer confidence in making online shopping transactions with Zalora is supported by quality content, website design, and fun that has a positive contribution because Zalora users believe in shopping online. The antecedent of trust has almost the same perception, where the model if it provides quality information, the sense of trust will be higher and vice versa, if it provides inaccurate information, the sense of trust will decrease. The magnitude of the influence of trust will provide a good review for the intention to recommend to others.

Suggestions for further research for the online fashion business world to be able to strengthen the stimulus in order to increase the sense of trust and the intention to recommend that has been built previously. The enhanced stimulus is in the form of quality improvement in the online fashion business. By understanding consumers to Subsequent research adds a customer retention variable (maintaining customers) in order to expand market share.

\section{References}

[1] Al-Ansi, A., Olya, H. G. T., \& Han, H. (2019). Effect of general risk on trust, satisfaction, and recommendation intention for halal food. International Journal of Hospitality Management, 83(October), 210-219. https://doi.org/10.1016/j.ijhm.2018.10.017

[2] Al-Maghrabi, T., Dennis, C., Halliday, S. V., \& BinAli, A. (2011). Determinants of customer continuance intention of online shopping. International Journal of Business Science and Applied Management, 6(1), 41-65.

[3] Anderson, E. W., \& Sullivan, M. W. (1993). The Antecedents and Consequences of Customer Satisfaction for Firms. Marketing Science, 12(2), 125-143. https://doi.org/10.1287/mksc.12.2.125

[4] Arjoon, S., \& Rambocas, M. (2011). Ethics and Customer Loyalty: Some Insights into Online Retailing Services. International Journal of Business and Social Science, 2(14), 135-142. www.ijbssnet.com

[5] Bo, X., \& Benbasat, I. (2007). e-commerce product recommendation agents: Use, characteristics, and impact. MIS Quarterly: Management Information Systems, 31(1), 137-209. https://doi.org/10.2307/25148784

[6] Cheung, C. M. K., Shen, X. L., Lee, Z. W. Y., \& Chan, T. K. H. (2015). Promoting sales of online games through customer engagement. Electronic Commerce Research and Applications, 14(4), 241-250. https://doi.org/10.1016/j.elerap.2015.03.001

[7] De Ruyter, K., Wetzels, M., \& Bloemer, J. (1998). On the relationship between perceived service quality, service loyalty, and switching costs. International Journal of Service Industry Management, 9(5), 436-453. https://doi.org/10.1108/09564239810238848

[8] Dodds, W. B., Monroe, K. B., \& Grewal, D. (1991). Jurnal Tugas Ind 3. XXVIII(August), 307-319.

[9] Fan, Q., Yul Lee, J., \& in Kim, J. (2013). The impact of website quality on flow-related online shopping behaviors in C2C e-marketplaces: A cross - national study. Managing Service Quality: An International Journal, 23(5), 364-387. https://doi.org/10.1108/MSQ-11-2012-0150

[10] Garbarino, E., \& Johnson, M. S. (1999). The Different Roles of Satisfaction, Trust, and Commitment in Customer Relationships. Journal of Marketing, 63(2), 70-87. https://doi.org/10.1177/002224299906300205

[11] Gehrke, D., \& Turban, E. (2003). Determinants of successful Website design: relative importance and recommendations for effectiveness. 00(c), 8. https://doi.org/10.1109/hicss.1999.772943

[12] Harris, L. C., \& Goode, M. M. H. (2004). The four levels of loyalty and the pivotal role of trust: A study of online service dynamics. Journal of Retailing, 80(2), 139-158. https://doi.org/10.1016/j.jretai.2004.04.002

[13] Hart, P., \& Saunders, C. (1997). Power and Trust: Critical Factors in the Adoption and Use of Electronic Data Interchange. Organization Science, 8(1), 23-42. https://doi.org/10.1287/orsc.8.1.23

[14] Hausman, A. V., \& Siekpe, J. S. (2009). The effect of web interface features on consumer online purchase intentions. Journal of Business Research, 62(1), 5-13. https://doi.org/10.1016/j.jbusres.2008.01.018

[15] Heijden, H. Van Der, Verhagen, T., \& Creemers, M. (2003). Understanding online purchase intentions: Contributions from technology and trust perspectives. European Journal of Information Systems, 12(1), 41-48. https://doi.org/10.1057/palgrave.ejis.3000445

[16] Hwang, Y., \& Kim, D. J. (2007). Customer self-service systems: The effects of perceived Web quality with service contents on enjoyment, anxiety, and e-trust. Decision Support Systems, 43(3), 746-760. https://doi.org/10.1016/j.dss.2006.12.008

[17] Jones, M. A., Mothersbaugh, D. L., \& Beatty, S. E. (2002). Why customers stay: Measuring the underlying dimensions of services switching costs and managing their differential strategic outcomes. Journal of Business Research, 55(6), 441-450. https://doi.org/10.1016/S01482963(00)00168-5

[18] Kim, G., Shin, B., \& Lee, H. G. (2009). Understanding dynamics between initial trust and usage intentions of mobile banking. Information Systems Journal, 19(3):283-311. https://doi.org/https://doi.org/10.1111/j.1365-2575.2007.00269.x

[19] Liang, T. P., \& Lai, H. J. (2002). Effect of store design on consumer purchases: An empirical study of online bookstores. Information and Management, 39(6), 431-444. https://doi.org/10.1016/S0378-7206(01)00129-X

[20] Liao, C., Palvia, P., \& Lin, H. N. (2006). The roles of habit and website quality in e-commerce. International Journal of Information Management, 26(6), 469-483. https://doi.org/10.1016/j.jijinfomgt.2006.09.001

[21] Lowry, P. B., Gaskin, J. E., Twyman, N. W., Hammer, B., \& Roberts, T. L. (2013). Taking "fun and games" seriously: Proposing the hedonicmotivation system adoption model (HMSAM. Journal of the Association of Information Systems, 14(11), 617-671.

[22] McKnight, D. H., Choudhury, V., \& Kacmar, C. (2002). Developing and validating trust measures for e-commerce: An integrative typology. Information Systems Research, 13(3), 334-359. https://doi.org/10.1287/isre.13.3.334.81

[23] Nowlin, E. L., Walker, D., \& Anaza, N. A. (2018). How does salesperson connectedness impact performance? It depends upon the level of internal volatility. Industrial Marketing Management, 68(November 2017), 106-113. https://doi.org/10.1016/j.indmarman.2017.10.007

[24] Ranaweera, C., \& Prabhu, J. (2003). The influence of satisfaction, trust, and switching barriers on customer retention in a continuous purchasing setting. International Journal of Service Industry Management, 14(3-4), 374-395. https://doi.org/10.1108/09564230310489231

[25] Rouibah, K. (2008). Social usage of instant messaging by individuals outside the workplace in Kuwait: A structural equation model. In 
Information Technology and People (Vol. 21, Issue 1). https://doi.org/10.1108/09593840810860324

[26] Shankar, V., Smith, A. K., \& Rangaswamy, A. (2003). Customer satisfaction and loyalty in online and offline environments. International Journal of Research in Marketing, 20(2), 153-175. https://doi.org/10.1016/S0167-8116(03)00016-8

[27] Singh, J., \& Sirdeshmukh, D. (2000). Agency and trust mechanisms in consumer satisfaction and loyalty judgments. Journal of the Academy of Marketing Science, 28(1), 150-167. https://doi.org/10.1177/0092070300281014

[28] Strauss, G. (2012). Douglas McGregor, Revisited: Managing the Human Side of Enterprise by Gary Heil, Warren Bennis, and Deborah C. Stephens, New York: Wiley, 2000, 196 pp., ISBN 0-471-31462-5. Relations Industrielles, 57(1), 198. https://doi.org/10.7202/006718ar

[29] Tang, J., Hu, X., \& Liu, H. (2013). Social recommendation: a review. Social Network Analysis and Mining, 3(4), 1113-1133. https://doi.org/10.1007/s13278-013-0141-9

[30] Venkatesh, V., \& Davis, F. D. (2000). A theoretical extension of the Technology Acceptance Model: Four longitudinal field studies. Management Science, 46(2), 186-204. https://doi.org/10.1287/mnsc.46.2.186.11926

[31] Walczuch, R., \& Lundgren, H. (2004). Psychological antecedents of institution-based consumer trust in e-retailing. Information and Management, 42(1), 159-177. https://doi.org/10.1016/j.im.2003.12.009

[32] Wang, E. S. T., \& Lin, R. L. (2017). Perceived quality factors of location-based apps on trust, perceived privacy risk, and continuous usage intention. Behavior and Information Technology, 36(1), 2-10. https://doi.org/10.1080/0144929X.2016.1143033

[33] Wei, K., Huang, J., \& Fu, S. (2007). A survey of E-commerce recommender systems. Proceedings - ICSSSM'07: 2007 International Conference on Service Systems and Service Management, 2006. https://doi.org/10.1109/ICSSSM.2007.4280214

[34] Yoo, B., Yoo, N. D., \& Donthu, N. (2001). Developing a Scale to Measure the Perceived Quality of an Internet Shopping Site (SITEQUAL). Quarterly Journal of Electronic Commerce, 2(1), 31-47.

[35] ZALORA. (2020). ZALORA INDONESIA RECEIVES AN UPGRADE OF ORDERS AS MUCH AS 14X FOLD DURING THE 12.12 HARBOLNAS PERIOD 2020.

[36] Zhu, T., Harrington, P., Li, J., \& Tang, L. (2014). Bundle recommendation in eCommerce. SIGIR 2014 - Proceedings of the 37th International ACM SIGIR Conference on Research and Development in Information Retrieval, 657-666. https://doi.org/10.1145/2600428.2609603 